Jurnal Keperawatan Silampari

Volume 5, Nomor 1, Desember 2021

e-ISSN: 2581-1975

p-ISSN: 2597-7482

DOI: https://doi.org/10.31539/jks.v5i1.2366

\title{
TERAPI APPLIED BEHAVIOR ANALYSIS MENINGKATKAN KEMAMPUAN INTERAKSI SOSIAL PADA ANAK AUTISME UMUR 7-12 TAHUN
}

\author{
Mochamad Heri ${ }^{1}$, Komang Gde Trisna Purwantara ${ }^{2}$, Putu Agus Ariana ${ }^{3}$ \\ Sekolah Tinggi Ilmu Kesehatan Buleleng ${ }^{1,2,3}$ \\ mochamad_heri@rocketmail.com ${ }^{1}$
}

\begin{abstract}
ABSTRAK
Penelitian ini bertujuan untuk mengetahui pengaruh terapi applied behavior analysis terhadap interaksi sosial pada anak autisme umur 7-12 tahun di SDLB SLB Negeri 2 Buleleng. Jenis penelitian ini adalah penelitian pra-eksperimental dengan rancangan one group pre-post test design. Hasil analisis univariat sebagian besar responden berjenis kelamin laki-laki 53 responden $(85,5 \%)$, tingkat interaksi sosial sedang berjumlah 46 responden $(74,2 \%)$ anak autis sebelum diberikan perlakuan dan tingkat interaksi sosial tinggi berjumlah 40 responden $(64,5 \%)$ anak autis setelah diberikan perlakuan. Hasil penelitian ini menunjukan ada pengaruh terapi applied behavior analysis dengan tingkat interaksi sosial tinggi berjumlah 40 responden $(64,5 \%)$ anak autis setelah diberikan perlakuan. Hasil analisa data dengan uji wilcoxon dapatkan nilai 0,000 atau $p<\alpha(0,05)$. Simpulan, ada pengaruh terapi applied behavior analysis terhadap interaksi sosial pada anak autisme umur 7-12 tahun di SDLB SLB Negeri 2 Buleleng.
\end{abstract}

Kata Kunci: Applied Behavior Analysis, Autisme, Interaksi Sosial

\begin{abstract}
This study aims to determine the effect of applied behavior analysis therapy on social interaction in children with autism aged 7-12 years at SDLB SLB Negeri 2 Buleleng. The type of this research is pre-experimental research with one group pre-post test design. The results of the univariate analysis, most of the respondents were male 53 respondents $(85.5 \%)$, the level of moderate social interaction was 46 respondents $(74.2 \%)$ autistic children before being given treatment, and the high level of social interaction was 40 respondents $(64,5 \%)$ autistic children after being given treatment. The results of this study indicate an effect of Applied Behavior Analysis therapy with a high level of social interaction totaling 40 respondents (64.5\%) of autistic children after being given treatment. The results of data analysis with the Wilcoxon test get a value of 0.000 or $p<\alpha$ (0.05). In conclusion, Applied Behavior Analysis therapy has an effect on social interaction in children with autism aged 7-12 years at SDLB SLB Negeri 2 Buleleng.
\end{abstract}

Keywords: Applied Behavior Analysis, Autism, Social Interaction 


\section{PENDAHULUAN}

Hambatan perkembangan sering kali dialami oleh anak. Salah satu hambatan perkembangan yang sulit ditangani yaitu autisme. Autisme yang secara khusus yaitu childhood autism (autisme masa anak-anak) adalah adanya gangguan perkembangan pervasif yang didefinisikan oleh adanya perkembangan abnormal atau gangguan yang nyata sebelum usia tiga tahun, dengan tipe karakteristik tidak normalnya semua tiga bidang psikopatologi yaitu interaksi sosial, komunikasi dan stereotip atau perilaku berulang (Fitriyah, 2019).

Autisme biasanya terdeteksi pada anak sebelum usia 1,5-2 tahun. Namun, ada juga gejala sejak usia bayi dengan keterlambatan interaksi sosial dan bahasa (progresi) (Wahyu et al., 2018). Anak autis bisa mencapai normal tapi sebelum usia 2 tahun perkembangannya berhenti dan mundur, serta muncul ciri-ciri autisme (Iskandar \& Indaryani, 2020).

Kasus autis di masih banyak terjadi di dunia, berdasarkan World Health Organize (WHO) pada tahun 2017 di dunia diperkirakan 1 dari 160 anak menderita autisme (WHO, 2017). Saat ini di Indonesia belum ada data statistik jumlah penyandang Autisme. Namun individu dengan autisme diperkirakan sudah semakin meningkat. Hal ini dapat dilihat dari angka kunjungan di rumah sakit umum, rumah sakit jiwa pada klinik tumbuh kembang anak yang cukup bermakna dari tahun ke tahun (Iskandar \& Indaryani, 2020).

Interaksi sosial merupakan kesulitan yang nyata bagi anak-anak berkebutuhan khusus, terutama dalam melakukan hubungan sosial dengan teman sebaya serta lingkungannya (Panzilion et al., 2021; Padila et al., 2021). Interaksi sosial adalah hubungan manusia dengan manusia lainnya atau hubungan manusia dengan kelompok atau hubungan kelompok dengan kelompok. Anak autisme sulit dalam melakukan komuniasi dan berinteraksi dengan lingkungannya, hal ini akibat keterlambatan dan gangguan pada perkembangannya baik itu gangguan motorik halus maupun kasar (Jessy \& Diswantika, 2019).

Penanganan masalah interaksi sosial anak dengan autisme harus dilakukan sedini mungkin dan perlu dukungan dari berbagai pihak seperti orang tua, guru dan tenaga kesehatan. Salah satu cara untuk menangani permasalahan interaksi sosial pada anak autisme yaitu dengan metode Applied Behavior Analysis (ABA). ABA merupakan sebuah ilmu terapan yang digunakan untuk mempelajari perilaku autisme agar dapat diketahui perilaku mana yang ada kejanggalan sehingga dapat diberikan intervensi yang sesuai dengan bagian tersebut (Iskandar \& Indaryani, 2020).

Anak autis dan anak berkebutuhan khusus lainnya di Indonesia mendapatkan layanan pendidikan selayaknya anak-anak lainnya yakni melalui pendidikan inklusif (Permendiknas RI Nomor 70 Tahun 2009 Pasal 1 tentang Pendidikan Inklusif, 2009). Dalam peraturan menteri nomor 111 tahun 2014 mempertegas peran bimbingan dan konseling di sekolah yang juga membawahi jenjang sekolah dasar dan juga sekolah luar biasa maupun inklusif. Sehingga dalam penyelenggaraannya diperlukan adanya kerjasama guru kelas, guru bimbingan dan konseing, psikolog dan pihak-pihak lain yang terkait dengan masalah yang dihadapi anak didik (Heri et al., 2020).

Perkembangan pada anak meliputi beberapa aspek, salah satunya yaitu aspek fisik. Pertumbuhan dan perkembangan merupakan suatu hal yang sangat penting bagi mahluk hidup yaitu sebagai upaya untuk mempertahankan kelangsungan hidup dan melestarikan keturunan. Kelompok anak yang beresiko tinggi mengalami hambatan pertumbuhan dan perkembangan rentang usia 6-12 tahun, dampak autisme bagi 
kesehatan berkaitan dengan penyakit serius sehingga kejadian autisme ini perlu mendapatkan perhatian khusus dan dilakukan pencegahan sedini mungkin karena jika dibiarkan akan terus mengganggu generasi penerus (Heri \& Ariana, 2018).

Bimbingan kelompok merupakan layanan paling tepat dalam mengatasi masalah interaksi sosial anak autis. Berbeda dengan layanan bimbingan kelompok pada umumnya, bahwa bimbingan kelompok kali ini akan melibatkan anak normal dalam pelaksanaannya. Peran anak normal dalam kegiatan kelompok mampu membantu anak autis dalam berinteraksi sosial (Heri \& Ariana, 2018).

Berdasarkan studi pedahuluan yang dilakukan di SDLB SLB Negeri 2 Buleleng pada tanggal 25 Januari 2019 diketahui dari 91 siswa terdapat 84 siswa yang mengalami autisme. Dari hasil wawancara dengan 10 siswa (11\%) dengan autisme 7 orang (70\%) siswa tidak merespon ketika ditanya, menjauhi kontak mata dan menyendiri, 3 orang (30\%) merespon dengan dengan singkat, mempertahankan kontak mata kurang dari 2 detik.

Penelitian sebelumnya sudah pernah ada yang meneliti berhubungan dengan penelitian ini, namun belum ada yang lebih spesifik meneliti tentang pengaruh terapi applied behavior analysis terhadap interaksi sosial pada anak autisme umur 7-12 tahun. Berdasarkan uraian diatas penelitian ini bertujuan untuk mengetahui pengaruh terapi applied behavior analysis terhadap interaksi sosial pada anak autisme umur 7-12 tahun di SDLB SLB Negeri 2 Buleleng.

\section{METODE PENELITIAN}

Jenis penelitian pra-eksperimental dengan menggunakan rancangan one group pre-post test design. Populasi dalam penelitian ini adalah anak usia 7-12 tahun yang mengalami autisme di SDLB SLB Negeri 2 Buleleng sebanyak 74 anak. Penentuan sampel dengan teknik probability sampling. Sampel dalam penelitian ini adalah seluruh anak usia 7-12 tahun yang masuk kriteria inklusi yaitu sebanyak 62 anak. Instrumen yang digunakan dalam penelitian ini untuk mengukur tingkat interaksi sosial yaitu lembar observasi Autisme Treatment Evalua tion Checklist (ATEC) domain interaksi sosial yang telah dimodifikasi.

Pada lembar observasi terdapat dua kolom jawaban pertanyaan yaitu iya dan tidak. Nilai dari jawaban iya yaitu bernilai 1 dan nilai untuk jawaban tidak yaitu bernilai 0. Kriteria hasil skor dikelompokkan menjadi tiga kategori yaitu 1. Kategori Kurang: 06, Kategori Sedang: 7-13, dan Kategori Baik: 14-20. Pelaksanaan Penelitian dilakukan di wilayah kerja Puskesmas Buleleng 1 pada bulan Mei 2019. Lokasi penelitian adalah di SDLB SLB Negeri 2 Buleleng Propinsi Bali.

\section{HASIL PENELITIAN \\ Analisis univariat \\ Karakteristik Responden}

Tabel. 1

Distribusi Frekuensi Responden

Berdasarkan Jenis Kelamin

\begin{tabular}{lll}
\hline Jenis Kelamin & Frekuensi & Presentase $(\%)$ \\
\hline Perempuan & 9 & 14.5 \\
Laki-laki & 53 & 85.5 \\
\hline Total & 62 & 100.0 \\
\hline
\end{tabular}


Berdasarkan tabel 1 dapat dilihat bahwa dari 62 responden sebagian besar responden dengan jenis kelamin laki-laki yaitu 53 responden $(85.5 \%)$ dan sebagian kecil dengan dengan jenis kelamin perempuan yaitu 9 responden $(14.5 \%)$.

Tabel. 2

Distribusi Responden

Berdasarkan Umur

\begin{tabular}{lcc}
\hline Umur Anak & Frekuensi $(\mathrm{N})$ & Persentase $(\%)$ \\
\hline 7 Tahun & 4 & 6.5 \\
8 Tahun & 3 & 4.8 \\
9 Tahun & 15 & 24.2 \\
10 Tahun & 20 & 32.3 \\
11 Tahun & 13 & 20.9 \\
12 Tahun & 7 & 11.3 \\
\hline Jumlah & 62 & 100 \\
\hline
\end{tabular}

Berdasarkan tabel 2 menunjukan bahwa dari 62 responden, sebagian besar anak yang mengalami autisme yaitu berumur 10 tahun sebanyak 20 orang $(32.3 \%)$ dan anak yang mengalami autisme rendah berumur 8 tahun sebanyak 3 orang $(4.8 \%)$.

Tabel. 3

Data Hasil Penelitian Interaksi Sosial

Sebelum Diberikan Perlakuan

\begin{tabular}{ccc}
\hline Tingkat Interaksi Sosial & Frekuensi $(\mathrm{N})$ & Persentase $(\%)$ \\
\hline Ringan & 4 & 6.5 \\
Sedang & 46 & 74.2 \\
Tinggi & 12 & 19.4 \\
\hline Jumlah & 62 & 100 \\
\hline
\end{tabular}

Berdasarkan tabel 3 menunjukan bahwa dari 62 responden, sebagian anak autisme dengan interaksi sosial sedang sebanyak 46 anak (74.2\%) sebelum diberikan perlakuan dan anak autisme dengan interaksi sosial ringan sebanyak 4 anak $(6.5 \%)$ sebelum diberikan perlakuan.

Tabel. 4

Data Hasil Penelitian Interaksi Sosial

Setelah Diberikan Perlakuan

\begin{tabular}{ccc}
\hline Tingkat Interaksi Sosial & Frekuensi $(\mathrm{N})$ & Persentase $(\%)$ \\
\hline Ringan & 0 & 0 \\
Sedang & 22 & 35.5 \\
Tinggi & 40 & 64.5 \\
\hline Jumlah & 62 & 100 \\
\hline
\end{tabular}

Berdasarkan tabel 4 menunjukan bahwa dari 62 responden, sebagian besar anak mengalami autisme dengan interaksi sosial tinggi sebanyak 40 anak (64.5\%) setelah diberikan perlakuan dan anak autisme dengan interaksi sosial sedang sebanyak 22 anak (35.5\%) setelah diberikan perlakuan. 


\section{Analisis Bivariat}

Tabel. 5

Tabel Hasil Uji Wilcoxon

\begin{tabular}{cc}
\hline & Pre Test - Post Test \\
\hline $\mathrm{Z}$ & -6.898 \\
\hline Asymp. Sig. (2-tailed) & 0.000 \\
\hline
\end{tabular}

Berdasarkan tabel 5 hasil analisis uji wilcoxon dapat dilihat pada asymp. sig. (2tailed) (0.000) yang berarti $\mathrm{p}<0.05$ maka disimpulkan ada pengaruh terapi applied behavior analysis terhadap interaksi sosial pada anak autisme umur 7-12 tahun di SDLB SLB Negeri 2 Buleleng.

\section{PEMBAHASAN}

\section{Analisis Univariat}

Berdasarkan tabel 1 dapat dilihat dari hasil penelitian tentang karakteristik responden mayoritas jenis kelamin adalah laki-laki. Menurut peneliti ini dikarenakan anak laki-laki cenderung mengalami kelainan genesis yang menyebabkan gangguan sel otak. Autisme terjadi akibat kelainan kromosom X, pada perempuan memiliki dua kromosom X sehingga, jika salah satu kromosom mengalami kelainan, masih ada kromosom X kedua. Didukung penelitian sebelumnya oleh Putri et al., (2019) menyebutkan bahwa sebagian besar orang tua memiliki anak penyandang GSA (Gangguan Spektrum Autisme) berjenis kelamin laki-laki (61,5\%).

Penelitian ini mendukung beberapa penelitian sejenis bahwa autis lebih banyak dialami oleh anak laki- laki. Laki-laki lebih banyak memproduksi hormon testosterone sementara perempuan lebih banyak memproduksi hormon estrogen. Hormon estrogen memiliki efek terhadap suatu gen pengatur fungsi otak yang disebut Retinoic AcidRelated Orphan Receptor-alpha. Hormon Testosteron mengahambat kerja Retinoic Acid-Related Orphan Receptor-alpha, sementarahormon estrogen justru meningkatkan kinerja Retinoic Acid-Related Orphan Receptor-alpha (Widiarti et al., 2021).

Berdasarkan tabel 2 karakteristik umur anak didapatkan bahwa sebagian besar anak yang mengalami autisme yaitu berumur 10 tahun sebanyak 20 orang (32.3\%) dan anak yang mengalami autisme rendah berumur 8 tahun sebanyak 3 orang (4.8\%). Menurut peneliti, anak autis yang terdeteksi sebelum usia 3 tahun dan tidak segera dilakukan terapi maka akan berdampak pada perkembangan yang cenderung semakin menurun seperti tidak adanya kontak mata, tidak menunjukan respon terhadap lingkungan. Sejalan dengan penelitian Widiarti et al., (2021) menyebutkan bahwa pada usia sekolah kelainan yang dialami oleh anak autisme dapat terlihat dengan jelas, terutama dalam pergaulan interaksi sosial.

Berdasarkan tabel 3 menunjukan hasil bahwa dari 62 responden, sebagian anak autisme dengan interaksi sosial sedang sebanyak 46 anak (74.2\%) sebelum diberikan perlakuan dan anak autisme dengan interaksi sosial ringan sebanyak 4 anak ( $6.5 \%$ ) sebelum diberikan perlakuan. Menurut peneliti, anak autisme mempunyai gangguan dalam aspek interaksi sosial yaitu tidak tertarik untuk bermain bersama teman, lebih suka menyendiri, tidak ada atau sedikit kontak mata, menghindar untuk bertatapan, senang menarik tangan orang lain untuk melakukan apa yang diinginkan.

Hasil penelitian ini sejalan dengan penelitian yang dilakukan oleh Widiarti et al., (2021) sebelum diberikan perlakuan masih ada responden yang kurang mampu (6.5\%) dalam melakukan permainan squisy. 
Berdasarkan tabel 4 menunjukan hasil penelitian bahwa dari 62 responden, sebagian besar anak mengalami autisme dengan interaksi sosial tinggi sebanyak 40 anak (64.5\%) setelah diberikan perlakuan dan anak autisme dengan interaksi sosial sedang sebanyak 22 anak (35.5\%) setelah diberikan perlakuan. Menurut peneliti, kemampuan interaksi sosial dengan kategori tinggi, kemampuan memahami detail anak dengan autisme secara umum dianggap lebih kuat daripada anak yang berkembang secara normal. Pada anak autisme dapat mengembangkan fantasi, empati dan berbagai jenis perasaan lain, serta membangun kedekatan.

Hasil penelitian ini sejalan dengan penelitian yang dilakukan oleh Iskandar \& Indaryani (2020) menyatakan bahwa adanya peningkatan kemampuan interaksi sosial pada anak autis sebelum (25\%) dan setelah (75\%) dilakukan terapi bermain assosiatif. Permainan assosiatif merupakan suatu permainan yang mana ditandai dengan adanya interaksi anak saat bermain. Pada penelitian ini terlihat dari cara anak menyusun plastisin dikarton gambar yang membutuhkan kerjasama sehingga dapat terselesaikan dengan baik. Melalui permainan anak dapat mengembangkan dan memperluas sosialisasi, belajar untuk mengatasi persoalan yang timbul, mengenal nilai-nilai moral dan etika, belajar mengenal apa yang salah dan benar, serta bertanggung jawab terhadap sesuatu yang dibuatnya.

\section{Analisis Bivariat}

Berdasarkan tabel 5 menunjukkan bahwa ada pengaruh terapi applied behavior analysis terhadap interaksi sosial pada anak autisme umur 7-12 tahun di SDLB SLB Negeri 2 Buleleng.

Interaksi sosial adalah hubungan antara individu satu dengan individu yang lain, individu satu dapat mempengaruhi individu yang lain atau sebaliknya sehingga ada hubungan timbal balik, Pada anak autis, gangguan interaksi sosial ditandai dengan kegagalan membinahubungan sosial dengan teman sebaya, dimana mereka tidak mampu berbagi emosi, aktivitas, dan interes bersama. Sebelum dilakukan terapi applied behavior analysis, penilaian kemampuan interaksi sosial anak terlihat dari kontak mata, ekspresi wajah, gerakan-gerakan yang kurang fokus atau aneh yang berulang, kemampuan bermain dengan teman, dan keadaan emosi anak seperti menangis atau marah yang tiba-tiba. Keberhasilan terapi bagi penyandang autis dapat dilakukan dengan berbagai metode dan terapi, antara lain dengan terapi applied behavior analysis. Terapi tersebut dilakukan dengan cara memberikan perhatian, pelatihan dan pendidikan secara khusus bagi anak autis. Sehingga anak autis tersebut mampu mengembangkan dirinya dalam berkomunikasi maupun berinteraksi dengan teman-teman sebayanya

Dengan melakukan teori ABC dalam ABA secara berulang, anak autisme lamakelamaan akan mendapat pemahaman bahwa ketika kita melakukan tugas sesuai intruksi akan mendapatkan hadiah atau reward. Sehingga tugas-tugas yang diberikan juga akan memberikan pemahaman kepada anak autisme cara yang baik untuk mengungkapkan keinginan. Ketika ABA diterapkan terus menerus akan dapat merubah tingkat bahasa, kognitif, komunikasi dan interaksi sosialnya menjadi lebih baik (Ginting \& Fitrah, 2019).

Pernyataan tersebut didukung oleh penelitian yang di lakukan Jessy \& Diswantika (2019) hasil penelitian menunjukan efektivitas metode ABA dapat diketahui melalui respon positif oleh terapis. Namun respon positif ini diperoleh setelah beberapa kali pertemuan yang tingkat pembelajaranya disesuaikan dengan kondisi anak. 
Autisme merupakan spektrum sindroma kelainan neurologis yang tidak bisa disembuhkan. Dengan kelainan utamanya yaitu adanya gangguan pada trias komunikasi, imajinasi dan interaksi sosial. Dengan menggunakan teknik ABA dan berbagai modifikasinya anak dengan gangguan autisme bisa ditingkatkan kemampuanya untuk berkomunikasi dan interaksi sosial.

\section{SIMPULAN}

Ada pengaruh terapi applied behavior analysis terhadap interaksi sosial pada anak autisme umur 7-12 tahun di SDLB SLB Negeri 2 Buleleng.

\section{SARAN}

Berdasarkan hasil dari penelitian yang diperoleh, maka dapat diberikan saran yaitu bagi pusat layanan autis dan orang tua, pembaruan informasi perlu dilakukan secara rutin oleh terapis untuk meningkatkan pengetahuan, perilaku dan pola makan yang tepat sehingga diharapkan dapat memperbaiki dan mendukung perkembangan anak autis secara optimal.

\section{DAFTAR PUSTAKA}

Fitriyah, F. K. (2019). Pengaruh Permainan Tradisional Gobak Sodor dalam Bimbingan Kelompok terhadap Peningkatan Interaksi Sosial Anak Autis. Education and Human Development Journal, 4(2), 13-20. https://doi.org/10.33086/ehdj.v5i1.1293

Ginting, H. S. P., \& Fitrah, F. (2019). Hubungan antara Diet Anak Autisme dengan Perkembangan Anak Autisme di Pusat Layanan Autis Provinsi Bangka Belitung. Jurnal Kesehatan Masyarakat Aceh, 5(1), 357-365. https://doi.org/https://doi.org/10.37598/jukema.v5i1.699

Heri, M., \& Ariana, P. A. (2018). Pengaruh Media Flashcard terhadap Kemampuan Anak Usia 3-4 Tahun di TPA Yayasan Pantisila Paud Santo Rafael Singaraja. Jurnal Kesehatan Midwinerslion, 3(2), 221-227. https://ejournal.stikesbuleleng.ac.id/index.php/Midwinerslion/article/view/18

Heri, M., Astriani, N. M. D. Y., Purwantara, K. G. T., \& Sari, P. D. K. (2020). Terapi Okupasi Memasang Tali Sepatu terhadap Motorik Halus pada Anak Tunagrahita Sedang. Jurnal Keperawatan Silampari, 4(1), 239-247. https://doi.org/10.31539/jks.v4i1.1771

Iskandar, S., \& Indaryani, I. (2020). Peningkatan Kemampuan Interaksi Sosial pada Anak Autis melalui Terapi Bermain Assosiatif. JHeS (Journal of Health Studies), 4(2), 12-18. https://doi.org/10.31101/jhes.1048

Jessy, M., \& Diswantika, N. (2019). Efektivitas Terapi Applied Behavior Analysis (ABA) terhadap Perkembangan Bahasa Anak Berkebutuhan Khusus Autisme. Jurnal Cakrawala Pendas, 5(2), 105-109. https://doi.org/10.31949/jcp.v5i2.1353

Padila, P., Harsismanto, J., Andrianto, M. B., Sartika, A., \& Ningrum, D. (2021). Pengalaman Orangtua dalam Merawat Anak Retardasi Mental. Jurnal Kesmas Asclepius, 3(1), 9-16. https://doi.org/https://doi.org/10.31539/jka.v3i1.2163

Panzilion, P., Andri, J., \& Padila, P. (2021). Therapy Brain Gym terhadap Short Memory Anak Retardasi Mental. Jurnal Keperawatan Silampari, 4(2), 600-606. https://doi.org/https://doi.org/10.31539/jks.v4i2.2120 
Putri, A. M., Pramesti, W., \& Hapsari, R. D. (2019). Stres pada Orang Tua yang Memiliki Anak dengan Gangguan Spektrum Autisme. Jurnal Psikologi Malahayati, 1(1), 7-13. https://doi.org/10.33024/jpm.v1i1.1408

Wahyu, H., Betrianita, B., Pramesti, M., \& Padila, P. (2018). Pengaruh Metode Glenn Doman (Tahap 1 dan 2) terhadap Perkembangan Komunikasi Anak Autisme. Jurnal Keperawatan Silampari, 2(1), 169-183. https://doi.org/https://doi.org/10.31539/jks.v2i1.306

WHO. (2017). WHO South-East Asia Regional Strategy On Autism Spectrum Disorders. https://apps.who.int/iris/handle/10665/259505

Widiarti, A., Toemon, A. N., Mutiasari, D., \& Baboe, D. (2021). Kemampuan Komunikasi Anak Autisme setelah Pemberian Mainan Squisy. Jurnal Surya Medika, 6(2), 88-93. https://doi.org/10.33084/jsm.v6i2.2124 